\title{
Characteristics of the event mean concentration (EMCs) from rainfall runoff on mixed agricultural land use in the shoreline zone of the Yamuna River in Delhi, India
}

\author{
Deepshikha Sharma $\cdot$ Ruchi Gupta $\cdot$ \\ Ram Karan Singh • Arun Kansal
}

Received: 25 August 2011/Accepted: 27 November 2011/Published online: 21 December 2011

(C) The Author(s) 2011. This article is published with open access at Springerlink.com

\begin{abstract}
This paper is focused on the monitoring of the diffuse pollution characteristics from the agricultural land confining the River Yamuna in Delhi (capital of India). Agricultural fields surrounding the Yamuna river are direct nonpoint source of pollution impacting the river quality. The study includes watershed delineation for the River Yamuna using SWAT (2005) and land use classification for the city using GIS and remote sensing. Thereafter, the rainfall-runoff pollutant concentrations from the mixed agricultural land use were assessed for the 2006 and 2007 monsoon period (July-September). Runoff was measured using SCS method and grab samples of rainfall runoff were collected at three stations namely Old Delhi Railway Bridge (ODRB), Nizamuddin and Okhla bridge in Delhi. The samples were analysed for physico-chemical and biological parameters. Rainfall runoff and event mean concentrations (EMCs) for different water quality parameters were characterized and the effect of land use was analyzed. The average EMCs for BOD, COD, ammonia, nitrate, TKN, hardness, TDS, TSS, chlorides, sulfates,
\end{abstract}

D. Sharma $(\bowtie) \cdot$ A. Kansal

Department of Natural Resources, TERI University,

10, Institutional Area, Vasant Kunj, Delhi 110070, India

e-mail: deepshikha.k.sharma@gmail.com

A. Kansal

e-mail: akansal@teri.res.in

R. Gupta

Biomass Energy Technology Application, The Energy

and Resources Institute, Darbari Seth Block, IHC Complex,

Lodhi Road, New Delhi 110 003, India

e-mail: ruchig@teri.res.in

R. K. Singh

Department of Civil Engineering, Head-Research, Development \& Industrial Liaison, ITM University, Gurgaon, Haryana, India phosphate, fluorides and TC were $21.82 \mathrm{mg} / \mathrm{L}, 73.48 \mathrm{mg} / \mathrm{L}$, $72.68 \mu \mathrm{g} / \mathrm{L}, 229.87 \mu \mathrm{g} / \mathrm{L}, 15.32 \mu \mathrm{g} / \mathrm{L}, 11.36 \mathrm{mg} / \mathrm{L}, 117.44$ $\mathrm{mg} / \mathrm{L}, 77.60 \mathrm{mg} / \mathrm{L}, 117.64 \mathrm{mg} / \mathrm{L}, 135.82 \mathrm{mg} / \mathrm{L}, 0.08 \mathrm{mg} / \mathrm{L}$, $0.85 \mathrm{mg} / \mathrm{L}$ and $2,827.47 \mathrm{MPN} / 100 \mathrm{~mL}$, respectively. The EMCs of TSS, nitrogen and its compounds, phosphate and BOD were high.

Keywords Watershed - Land use - Digital elevation model $\cdot$ Diffuse pollution $\cdot$ Surface runoff

\section{Introduction}

Agriculture rainfall runoff is characterized as a nonpoint or diffuse source of water pollution. The pollutants in agricultural runoff may enter from both groundwater and surface water without passing through any treatment plants (Vaze and Chiew 2004; Crabtree et al. 2006; Terzakis et al. 2008). The common water contaminants from the diffuse sources can be grouped into various categories such as: sediments (TSS, TDS etc.); oil and toxic chemicals from automobiles (total petroleum hydrocarbons); nutrients from forest, animal and human activities (nitrogenous and phosphorus compounds like pesticides and biocides); heavy metals (As, $\mathrm{Cu}, \mathrm{Cd}, \mathrm{Ni}, \mathrm{Pb}$ and $\mathrm{Zn}$ ) (International Joint Commission 1974; Zoppou 2001; Ukabiala et al. 2010). The most common pollutants among the mentioned list are sediments and nutrients. These pollutants are washed off of agricultural fields and carried to streams, rivers, lakes and bays during rainstorms.

The economic viability of a river is threatened by its pollution which negatively impacts its users. In addition, it reduces the aesthetic value of the river. The pollutants released from various activities performed in domestic, industrial and agriculture sectors are discharged into rivers 
bringing about changes in the physical, chemical and biological characteristics of the river resulting in the depletion of dissolved oxygen (DO) and thus increasing deposition of organics, pathogens and nutrients in the water body (Kannel et al. 2011; Van der Velde et al. 2006; Cox 2003). The total event rainfall, antecedent dry period, cumulative seasonal rainfall and drainage area impact the quantity and quality of rainfall runoff prior to any treatment. Chui et al. (1982) and Tsihrintzis and Hamid (1997) studied the impact of the rainfall intensity and runoff volume upon the washed-off rate, and the dilution effects of accumulated contaminants, and their transportation to the receiving waters. The pollutants from storm are generated and transported in a diffuse manner with land use being one of the most important factors affecting the extent of pollution (Mallin et al. 2000; Lee et al. 2002; Tong and Chen 2002; Ackerman and Schiff 2003; Graves et al. 2004; Kim et al. 2005, 2007a, b; Yusop et al. 2005; McLeod et al. 2006; Zhao et al. 2007; Misra 2011). Candela et al. (2009) and Freni et al. (2010) concluded that both point and nonpoint sources cannot be neglected in water quality management.

Monitoring and estimation of diffuse pollution from the rainfall runoff is difficult in urbanized catchments with mixed land use pattern, since they are heterogeneous in nature and have anthropological interference. Over the years, several studies have been carried out to study the impact of point sources pollution on River Yamuna in Delhi (Bhargava 1983, 1986; Kazmi and Hansen 1997; Kazmi and Agarwal 2005; Paliwal et al. 2007; Sharma and Singh 2009; Parmar and Keshari 2011). Jamwal et al. (2008) estimated the diffuse pollution in urban areas of Delhi for the first time and stated that rainfall runoff from the agricultural area directly enters the river and from urban area reaches the river via wastewater drains, adding more pollutant loading. In this view, the present study was undertaken to monitor, characterize and estimate the pollutant concentration occurring due to rainfall runoff from the mixed agricultural land use (MAL) type. This MAL acts as a direct source of diffuse pollution to the River Yamuna in Delhi as it surrounds the banks of the river.

The study was carried out with following objectives: (1) land use classification of Delhi; (2) watershed delineation for area of interest (AOI); (3) calculating rainfall runoff from the watershed; (4) estimating the event mean concentrations (EMC) of runoff flows from MAL; and (5) analyzing relationships between EMCs and rainfallrunoff characteristics.

\section{Description of study area}

The River Yamuna is a major Himalayan river originating from Yamunotri glacier $(6,096 \mathrm{~m}$ above sea level) descending from Mount Kalindi and forming into a regular river from Yamunotri onwards. Its main tributaries are Hindon, Chambal, Betwa, Sind and Ken. It covers the following states: Himachal Pradesh, Uttar Pradesh, Uttarakhand, Haryana, Delhi, Rajasthan and Madhya Pradesh. Delhi is a mega metropolis situated on the banks of the River Yamuna with an area of $1,483 \mathrm{~km}^{2}(0.4 \%$ of total catchment) with a current population of approximately 17.6 million (http://www.indiastat.com). It enters from Palla traverses through the city and leaves it at Jaitpur near Okhla barrage (CPCB 2007).

Delhi has higher proportion of impervious area and sparse green area. In 2001, the annual drinking water requirement for the entire National Capital Region (NCR) was estimated as 2,310.07 million cubic meters (MCM) and the projections for the year 2021 are 4,374.27 MCM/ annum (NCRPB Report, n.a.). In 2001, the annual estimated water availability in Delhi from different surface water sources was 1,150.2 MCM. However, according to an MOU signed in 1994, the River Yamuna will provide 724 MCM of water to Delhi annually (Planning Commission, n.a), approximately $70 \%$, of Delhi's water requirements (Jain 2009). The total area of river zone is about 9,700 Ha, with approximately $1,600 \mathrm{Ha}$ of land is under water and 8,100 Ha is dry land (Delhi Master Plan 2021). This dry land consists of MAL pattern and is a direct source of rainfall runoff to the river resulting in the augmentation of diffuse pollution levels into the river (Jamwal et al. 2008).

The Government of India (GoI) initiated the Yamuna Action Plan (YAP) in 1993 and later extended to YAPII in 2004 (CPCB 2007) to restore the river quality http:// envfor.nic.in/nrcd/NRCD/YAP.htm. The class assigned to the River Yamuna in Delhi is ' $\mathrm{C}$ ', meaning 'direct consumption of river water without any conventional treatment is not safe for health'. Table 1 provides a comparison of the river quality in Delhi over the past 15 years, which shows that even after completion of YAP I and II the water quality of the river does not meet the required standards. The main causes of surface water pollution in Delhi are higher population density per square kilometer on the riverbanks, poor sanitation practices by residents, untreated domestic wastewater, untreated industrial effluents, diffuse pollution, agricultural runoffs, dead body dumping, cattle washing etc. However, while designing YAP, diffuse pollution arising from open defecation, crematoria and religious activities were addressed and no emphasis was given to the pollutant loading directly from MAL neighboring the riverbanks. In order to enact further on improving the river water quality, it is also important to estimate the EMCs of pollutants directly entering the River Yamuna from the shoreline. This would help environment modelers to critically address the issue of diffuse pollution 
and will also lend a hand in designing the pollution abatement schemes.

\section{Methodology}

The study was done for a period of 2 years, 2006 and 2007, for three monitoring stations. Samples were collected with spatial variation and no temporal variation. Time critical data measurements and laboratory analyses were performed immediately or at most within $12 \mathrm{~h}$ of collection, since most water quality parameters are time dependent. The samples were stored and refrigerated at $5^{\circ} \mathrm{C}$. Figure 1 illustrates the steps of methodology used for the study.

Land use classification and watershed delineation

The land use map was prepared using the IRS 1C-LISS-III imagery of 2006 using Supervised image classification method in ERDAS Imagine 9.0. On the basis of land use classification developed by NRSA (1995), the land use for Delhi was divided into five main classes namely water body; built-up area; forest; agricultural fields (sparse vegetation); and wasteland. Built-up area was further divided into high, medium and low dense urbanization. Thereafter, the watershed was delineated using Soil Water Assessment Tool (SWAT) 2005 model (Neitsch et al. 2005). The basic input data to SWAT included the digital elevation model (DEM), which was obtained from SRTM 90m Digital Elevation Data http://srtm.csi.cgiar.org/ and the land use classified above. The AOI consist of the watershed which was delineated for $0.2 \mathrm{~km}$ adjacent to the riverbanks where runoff directly enters the river during monsoon season.

\section{Diffuse pollution assessment}

In order to estimate the EMCs from the land use, the samples from three locations namely ODRB, Nizamuddin and Okhla were collected for 5 days (rainy days between July and September) from agricultural runoff sites using 'grab sampling method'. Three set of samples were analyzed for $\mathrm{pH}$, BOD, COD, DO, ammonia, phosphate, hardness, TKN, TDS, TSS, nitrates and total coliforms using standard methods (Standard Methods, APHA 1998). The average concentrations from all the sites were used to calculate the EMCs using the formula:EMC = Mass of pollutant transported during the event/Total flow during the event.

$\mathrm{EMC}=\frac{\sum Q_{i} C_{i}}{\sum Q_{i}}$

where $Q=$ discharge $\left(\mathrm{m}^{3} / \mathrm{s}\right)$ and $C=$ concentration $(\mathrm{mg} / \mathrm{L})$.

Hydrological data was obtained for each event from which includes antecedent dry day, event rainfall, runoff duration, rainfall intensity and runoff rate. The runoff was measured using Soil Conservation Service (SCS) curve number method (1964) and the meteorological data was

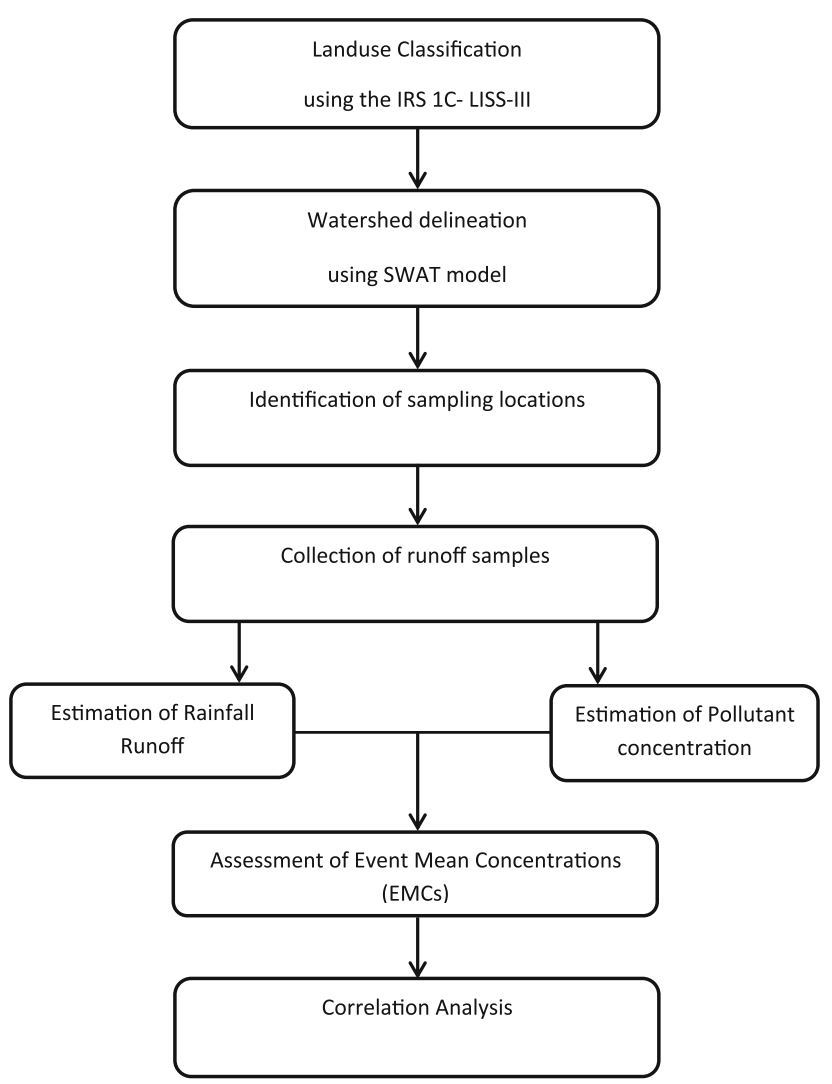

Fig. 1 Methodology flowchart

Table 1 Water quality of River Yamuna at Nizamuddin, Delhi, India

\begin{tabular}{|c|c|c|c|c|c|c|c|c|}
\hline \multicolumn{3}{|c|}{1995} & \multicolumn{3}{|c|}{2005} & \multicolumn{3}{|c|}{$2009^{\mathrm{a}}$} \\
\hline DO & BOD & Total coliforms & DO & BOD & Total coliforms & DO & BOD & Total coliforms \\
\hline 3.4 & 9.6 & 386,091 & 1.6 & 10.00 & $12,200,000$ & 0.0 & 23.00 & $22,516,660$ \\
\hline
\end{tabular}

The values for 1995 and 2005 have been taken from the Central Pollution Control Board (CPCB), Central Water Commission (CWC); Sources: CPCB 2000; CPCB 2007

${ }^{a}$ Units: DO and BOD: $\mathrm{mg} / \mathrm{L}$ and TC: MPN/100 mL 
obtained from Indian Meteorological Department (IMD) (Personal Communication). The soil composition of top layer is mainly 'sand type' (National Bureau of Soil Survey \& Land Use Planning and Soni et al. 2009).

\section{Results and discussion}

The land use classification (Fig. 2) showed that in 2006, $67 \%$ of city was urbanized $(99,361 \mathrm{Ha})$ with only $26 \%$ $(38,558 \mathrm{Ha})$ of the green area, which is either located near the riverbanks or at the outskirts of the city. The total river area under water is $1600 \mathrm{Ha}$ and the rest is wasteland which was 9,015 Ha. The land use pattern showed dense urbanization at the center of the city with only a few scattered patch of green area. Thereafter, DEM (Fig. 3a) was used to delineate the watershed which showed that the total area of watershed is 5,200 $\mathrm{Ha}$ (dry land) along the riverbed side (Fig. 3b) and comprises mainly MAL with very few urban settlements. Out of the total watershed area, 1,040 Ha of the catchment directly contributes to the diffuse pollution loading to the river. Therefore, only this watershed region was used to collect, characterize and estimate the rainfall-runoff pollutant concentrations. The three sampling locations were situated on the agricultural field adjacent to the river (Fig. 3b). Total ten rainfall events were selected to monitor the flow and runoff in the MAL (Table 2). The amount and intensity of the rainfall from MAL during the experiments were varied from 5 to $103.3 \mathrm{~mm}$ and from 1.11 to $41.32 \mathrm{~mm} / \mathrm{hr}$, respectively. Table 2 presents the hydrological data used consisting of rainfall characteristics and the runoff discharge calculated using SCS method.

The summary of descriptive statistical data of water quality concentrations measured at the three different locations done at $95 \%$ confidence level for mean is presented in Table 3. The mean ratio of COD to BOD was approximately 3.4. The level of organic pollutant concentrations was found to be higher than expected levels. The maximum range was observed for $\mathrm{TC}=5,399 \mathrm{MPN} /$ $100 \mathrm{~mL}$ followed by TSS $=155.4 \mathrm{mg} / \mathrm{L}$ and minimum for hardness $=5.9 \mathrm{mg} / \mathrm{L}$. The concentration of suspended solids found in river samples is $77.6 \mathrm{mg} / \mathrm{L}$, which is an indicator of soil erosion from the watershed. The concentration for other parameters ammonia, nitrates, TKN and phosphates were found as $72.68 \mu \mathrm{g} / \mathrm{L} ; 229.87 \mu \mathrm{g} / \mathrm{L}$; $15.32 \mu \mathrm{g} / \mathrm{L}$; and $0.8 \mathrm{mg} / \mathrm{L}$ respectively.

The estimated EMC of the pollutants from the MAL are presented in Table 4. The EMCs of BOD, COD, TDS, TSS
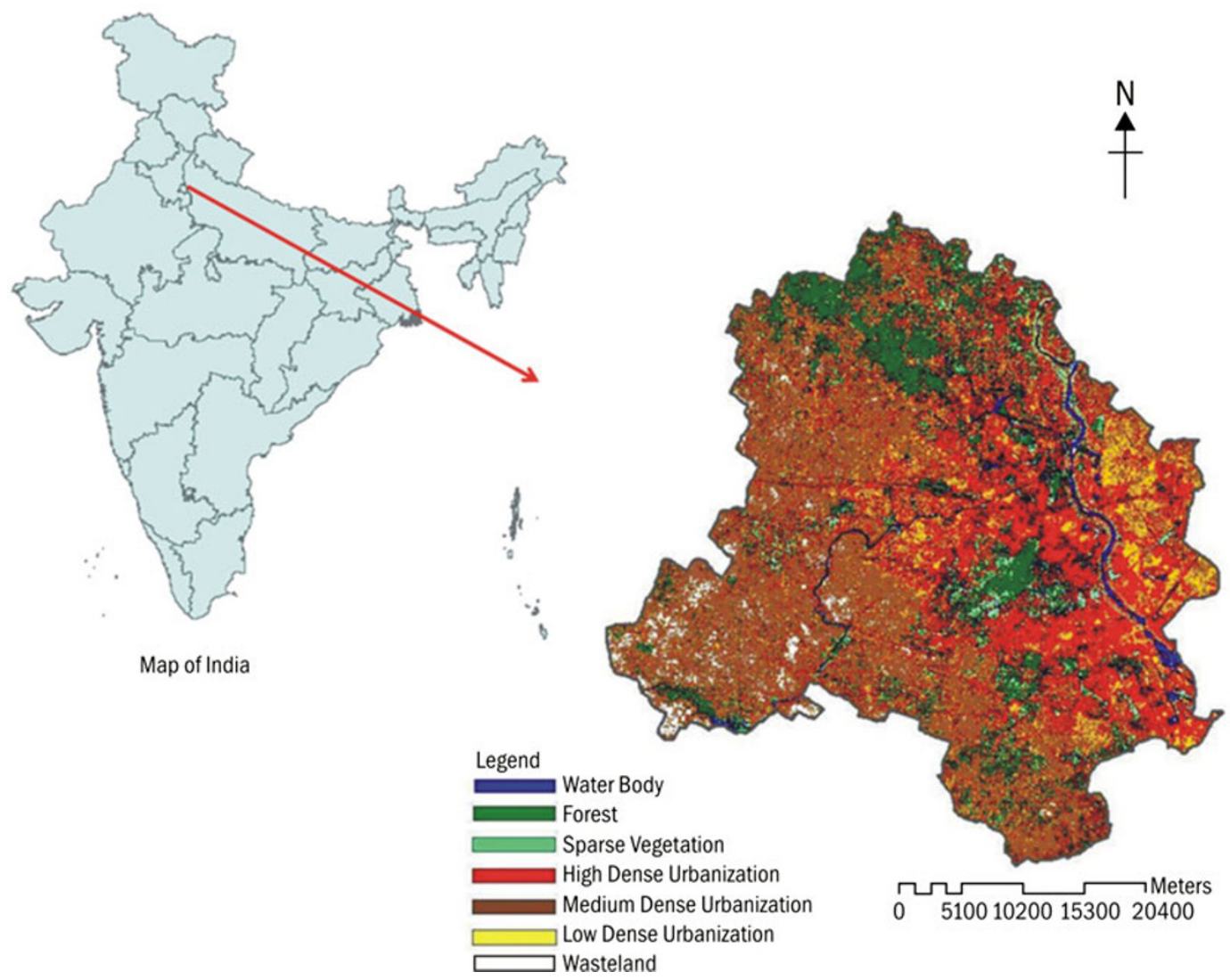

Fig. 2 Land use pattern in Delhi (2006) 


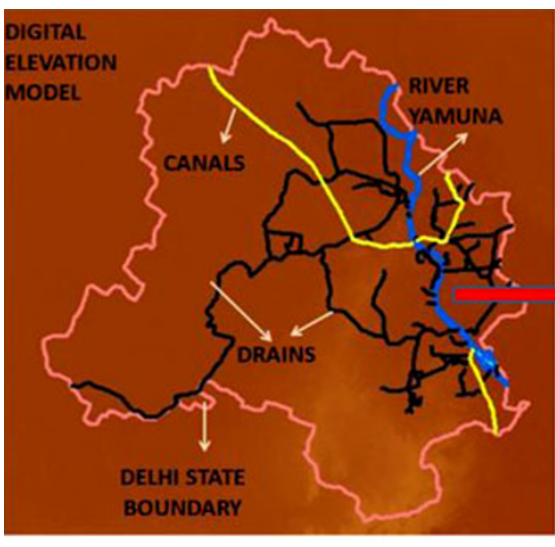

A

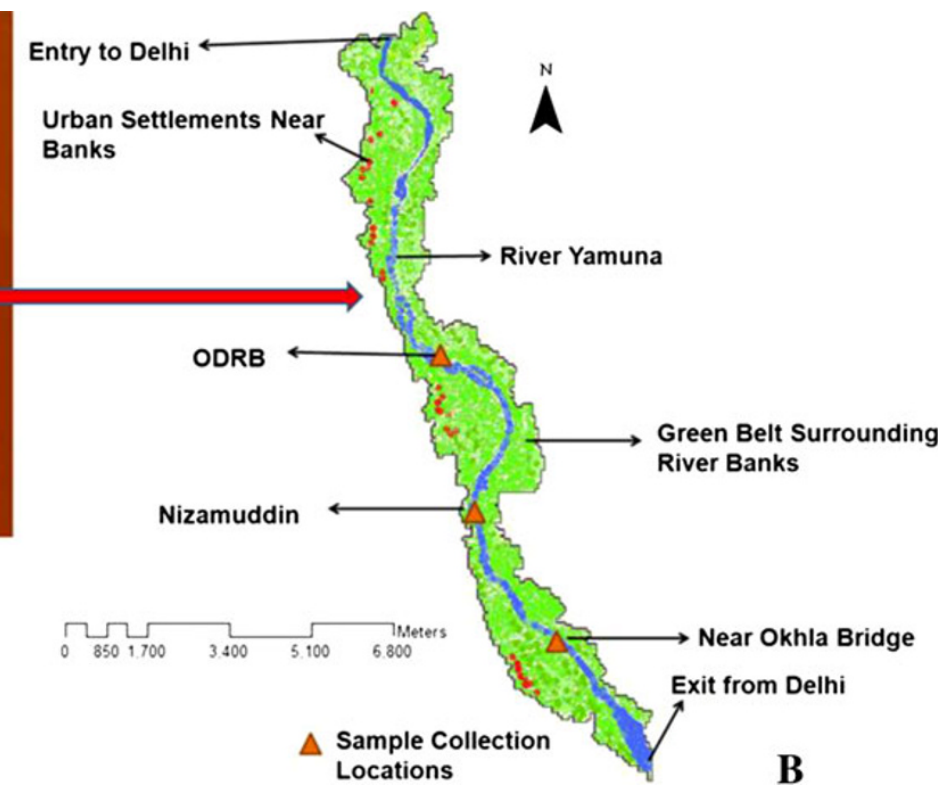

sampling locations on MAL (prepared in SWAT with $0.2 \mathrm{~km}$ of MAL on both banks of river)
Fig. 3 Description of study area. a Digital elevation model with state boundary, River Yamuna, canals and drains (DEM is taken from SRTM 90m data); b Watershed of River Yamuna (Delhi) with
Table 2 Rainfall characteristics and runoff discharge

\begin{tabular}{lclccc}
\hline Date & $\begin{array}{l}\text { Rainfall } \\
(\mathrm{mm})\end{array}$ & $\begin{array}{l}\text { Time } \\
(\mathrm{h})\end{array}$ & $\begin{array}{l}\text { Rainfall } \\
\text { intensity }(\mathrm{mm} / \mathrm{h})\end{array}$ & $\begin{array}{l}\text { Total } \\
\text { runoff }\left(\mathrm{m}^{3}\right)\end{array}$ & $\begin{array}{l}\text { Rainfall } \\
\text { runoff }\left(\mathrm{m}^{3} / \mathrm{s}\right)\end{array}$ \\
\hline 2006 & & & & & \\
$12 / 07 / 2006$ & 66.6 & 2.5 & 26.64 & 37.93 & 0.004214 \\
$27 / 07 / 2006$ & 103.3 & 2.5 & 41.32 & 146.15 & 0.01624 \\
$01 / 08 / 2006$ & 9.9 & 3.1 & 3.19 & 0.075 & $6.76 \mathrm{E}-06$ \\
$30 / 08 / 2006$ & 58.6 & 6.8 & 8.61 & 16.33 & 0.000667 \\
$03 / 09 / 2006$ & 30.3 & 1.5 & 20.2 & 3.21 & 0.000594 \\
2007 & & & & & \\
$14 / 07 / 2007$ & 15 & 3.4 & 4.41 & 0.065 & $5.28 \mathrm{E}-06$ \\
$24 / 07 / 2007$ & 28 & 2.5 & 11.2 & 2.50 & 0.000277 \\
$2 / 08 / 2007$ & 18 & 2.1 & 8.57 & 0.59 & $7.79 \mathrm{E}-05$ \\
$19 / 08 / 2007$ & 5 & 4.3 & 1.16 & 0.00007 & $4.63 \mathrm{E}-09$ \\
$2 / 09 / 2007$ & 5 & 4.5 & 1.11 & 0.00007 & $4.42 \mathrm{E}-09$ \\
\hline
\end{tabular}

and nitrogenous compounds showed higher values than expected. The mean of nitrogenous compounds are quite high with nitrates and TKN ranging from 211.35 to 243.35 and from 11.34 to $19.54 \mu \mathrm{g} / \mathrm{L}$, respectively.

Table 5 shows Pearson correlation coefficients between EMCs and rainfall-runoff characteristics. Correlation significant at $p<0.05$ are expressed in bold. COD, ammonia, hardness, TDS, TSS, sulfates, fluorides and TC are strongly related to rainfall intensity. COD, hardness and fluorides tend to decrease with increase rainfall, rainfall intensity and rainfall runoff. The assimilative capacity of a freshwater system increases with an increase in rainfall resulting in dissolution of inorganic salts. The positive correlation of rainfall intensity with $\mathrm{TC}$ concentration can be attributed to the availability of optimal conditions, i.e., moisture, temperature and nutrients which enhances the microbial activity. High correlation among TSS, rainfall, rainfall intensity and runoff clearly indicates that the runoff consists of suspended solids discharged from the MAL. Sulfides are also found to be positively correlated with the rainfall intensity and rainfall runoff. Most of the minerals are found positively correlated with rainfall runoff; this is due to the runoff fertilizers and manure from the surrounding agriculture fields.

It was observed that even during high rains only small amount of the total discharge is part of the runoff 
Table 3 Descriptive statistics of rainfall runoff water quality from MAL

\begin{tabular}{|c|c|c|c|c|c|c|c|c|c|c|c|c|c|}
\hline & $\begin{array}{l}\text { BOD } \\
(\mathrm{mg} / \mathrm{L})\end{array}$ & $\begin{array}{l}\text { COD } \\
(\mathrm{mg} / \mathrm{L})\end{array}$ & $\begin{array}{l}\text { Ammonia } \\
(\mu \mathrm{g} / \mathrm{L})\end{array}$ & $\begin{array}{l}\text { Nitrate } \\
(\mu \mathrm{g} / \mathrm{L})\end{array}$ & $\begin{array}{l}\text { TKN } \\
(\mu \mathrm{g} / \mathrm{L})\end{array}$ & $\begin{array}{l}\text { Hardness } \\
(\mathrm{mg} / \mathrm{L})\end{array}$ & $\begin{array}{l}\text { TDS } \\
(\mathrm{mg} / \mathrm{L})\end{array}$ & $\begin{array}{l}\text { TSS } \\
(\mathrm{mg} / \mathrm{L})\end{array}$ & $\begin{array}{l}\text { Chlorides } \\
\text { (mg/L) }\end{array}$ & $\begin{array}{l}\text { Sulfates } \\
(\mathrm{mg} / \mathrm{L})\end{array}$ & $\begin{array}{l}\text { Phosphate } \\
\text { (mg/L) }\end{array}$ & $\begin{array}{l}\text { Fluorides } \\
\text { (mg/L) }\end{array}$ & $\begin{array}{l}\text { TC (MPN/ } \\
100 \mathrm{~mL})\end{array}$ \\
\hline Mean & 21.82 & 73.48 & 72.68 & 229.87 & 15.32 & 11.36 & 117.44 & 77.60 & 117.64 & 135.82 & 0.08 & 0.85 & $2,827.47$ \\
\hline $\begin{array}{l}\text { Standard } \\
\text { error }\end{array}$ & 0.80 & 3.44 & 2.35 & 2.05 & 0.60 & 0.27 & 2.45 & 8.05 & 2.26 & 7.38 & 0.00 & 0.03 & 313.20 \\
\hline Median & 21.30 & 77.52 & 76.45 & 233.08 & 15.04 & 10.98 & 119.24 & 61.20 & 120.37 & 123.01 & 0.08 & 0.87 & $2,117.00$ \\
\hline $\begin{array}{l}\text { Standard } \\
\text { deviation }\end{array}$ & 4.36 & 18.86 & 12.87 & 11.23 & 3.26 & 1.49 & 13.43 & 44.10 & 12.38 & 40.43 & 0.01 & 0.14 & $1,715.46$ \\
\hline Range & 15.42 & 70.08 & 41.36 & 35.06 & 11.26 & 5.90 & 46.06 & 155.44 & 38.06 & 128.56 & 0.03 & 0.48 & $5,399.00$ \\
\hline Minimum & 15.08 & 34.08 & 46.48 & 209.89 & 9.88 & 9.24 & 87.68 & 44.30 & 95.68 & 83.58 & 0.06 & 0.62 & $1,179.00$ \\
\hline Maximum & 30.50 & 104.16 & 87.84 & 244.95 & 21.14 & 15.14 & 133.74 & 199.74 & 133.74 & 212.14 & 0.09 & 1.10 & $6,578.00$ \\
\hline Count & 30.00 & 30.00 & 30.00 & 30.00 & 30.00 & 30.00 & 30.00 & 30.00 & 30.00 & 30.00 & 30.00 & 30.00 & 30.00 \\
\hline $\begin{array}{l}\text { Confidence } \\
\text { level } \\
(95.0 \%)\end{array}$ & 1.63 & 7.04 & 4.80 & 4.19 & 1.22 & 0.56 & 5.02 & 16.47 & 4.62 & 15.10 & 0.00 & 0.05 & 640.56 \\
\hline
\end{tabular}

Table 4 Event wise descriptive statistical analysis of EMCs

\begin{tabular}{|c|c|c|c|c|c|c|c|c|c|c|c|c|c|}
\hline Event & $\begin{array}{l}\text { BOD } \\
(\mathrm{mg} / \mathrm{L})\end{array}$ & $\begin{array}{l}\text { COD } \\
(\mathrm{mg} / \mathrm{L})\end{array}$ & $\begin{array}{l}\text { Ammonia } \\
(\mu \mathrm{g} / \mathrm{L})\end{array}$ & $\begin{array}{l}\text { Nitrate } \\
(\mu \mathrm{g} / \mathrm{L})\end{array}$ & $\begin{array}{l}\text { TKN } \\
(\mu \mathrm{g} / \mathrm{L})\end{array}$ & $\begin{array}{l}\text { Hardness } \\
(\mathrm{mg} / \mathrm{L})\end{array}$ & $\begin{array}{l}\text { TDS } \\
(\mathrm{mg} / \mathrm{L})\end{array}$ & $\begin{array}{l}\text { TSS } \\
(\mathrm{mg} / \mathrm{L})\end{array}$ & $\begin{array}{l}\text { Chlorides } \\
\text { (mg/L) }\end{array}$ & $\begin{array}{l}\text { Sulfates } \\
\text { (mg/L) }\end{array}$ & $\begin{array}{l}\text { Phosphate } \\
\text { (mg/L) }\end{array}$ & $\begin{array}{l}\text { Fluorides } \\
\text { (mg/L) }\end{array}$ & $\begin{array}{l}\text { TC (MPN/ } \\
100 \mathrm{~mL})\end{array}$ \\
\hline 1 & 25.59 & 35.55 & 85.14 & 238.31 & 17.68 & 10.70 & 120.14 & 100.14 & 120.14 & 210.54 & 0.08 & 0.88 & $6,534.67$ \\
\hline 2 & 21.86 & 67.69 & 86.24 & 234.68 & 12.44 & 11.01 & 123.14 & 198.14 & 119.14 & 184.84 & 0.08 & 0.80 & $5,472.00$ \\
\hline 3 & 19.59 & 84.74 & 84.24 & 231.35 & 13.54 & 11.04 & 118.14 & 51.93 & 102.14 & 113.94 & 0.07 & 0.95 & $2,300.67$ \\
\hline 4 & 17.56 & 49.38 & 67.64 & 226.64 & 18.84 & 11.74 & 132.14 & 87.14 & 130.14 & 124.34 & 0.09 & 0.82 & $1,232.67$ \\
\hline 5 & 22.36 & 85.84 & 76.54 & 211.35 & 15.74 & 11.01 & 129.14 & 67.50 & 129.14 & 94.64 & 0.08 & 0.70 & $3,245.00$ \\
\hline 6 & 23.73 & 83.55 & 54.44 & 243.35 & 12.24 & 11.12 & 130.14 & 55.40 & 119.14 & 101.54 & 0.07 & 0.98 & $2,100.67$ \\
\hline 7 & 16.63 & 71.35 & 47.94 & 223.24 & 18.54 & 11.12 & 117.14 & 61.58 & 97.14 & 172.64 & 0.07 & 1.00 & $1,865.67$ \\
\hline 8 & 19.56 & 69.55 & 76.64 & 243.24 & 11.34 & 11.00 & 98.14 & 58.03 & 102.14 & 85.04 & 0.07 & 0.72 & $1,381.00$ \\
\hline 9 & 21.26 & 102.55 & 66.64 & 234.74 & 19.54 & 13.54 & 89.14 & 45.10 & 125.14 & 121.54 & 0.08 & 1.03 & $1,987.67$ \\
\hline 10 & 30.06 & 84.65 & 81.34 & 211.84 & 13.34 & 11.34 & 117.14 & 51.00 & 132.14 & 149.14 & 0.09 & 0.69 & $2,154.67$ \\
\hline Mean & 21.82 & 73.48 & 72.68 & 229.87 & 15.32 & 11.36 & 117.44 & 77.60 & 117.64 & 135.82 & 0.08 & 0.85 & $2,827.47$ \\
\hline $\begin{array}{l}\text { Standard } \\
\text { error }\end{array}$ & 1.25 & 6.17 & 4.20 & 3.66 & 0.98 & 0.26 & 4.38 & 14.45 & 4.04 & 13.24 & 0.00 & 0.04 & 562.10 \\
\hline Median & 21.56 & 77.45 & 76.59 & 233.01 & 14.64 & 11.08 & 119.14 & 59.81 & 119.64 & 122.94 & 0.08 & 0.85 & $2,127.67$ \\
\hline $\begin{array}{l}\text { Standard } \\
\text { deviation }\end{array}$ & 3.97 & 19.50 & 13.27 & 11.56 & 3.11 & 0.81 & 13.86 & 45.69 & 12.76 & 41.88 & 0.01 & 0.13 & $1,777.50$ \\
\hline Range & 13.43 & 67.00 & 38.30 & 32.00 & 8.20 & 2.84 & 43.00 & 153.04 & 35.00 & 125.50 & 0.02 & 0.34 & $5,302.00$ \\
\hline Minimum & 16.63 & 35.55 & 47.94 & 211.35 & 11.34 & 10.70 & 89.14 & 45.10 & 97.14 & 85.04 & 0.07 & 0.69 & $1,232.67$ \\
\hline Maximum & 30.06 & 102.55 & 86.24 & 243.35 & 19.54 & 13.54 & 132.14 & 198.14 & 132.14 & 210.54 & 0.09 & 1.03 & $6,534.67$ \\
\hline $\begin{array}{l}\text { Confidence } \\
\text { level } \\
(95.0 \%)\end{array}$ & 2.84 & 13.95 & 9.49 & 8.27 & 2.22 & 0.58 & 9.91 & 32.68 & 9.13 & 29.96 & 0.01 & 0.09 & $1,271.55$ \\
\hline
\end{tabular}

(Table 2). However, it cannot be neglected since it directly enters the river body and may result in amplification of the pollutant loadings from the agricultural area to the river. The agricultural runoff contains high amount of BOD, COD, solids, nitrogen and its compounds and other ions, which indicates the process of erosion and also justifies that the area under study is MAL. The result also implicates the applicability of pesticides and insecticides resulting in pollutants consisting of nitrogenous and phosphorus compounds.

\section{Conclusions}

The study explored the characteristics of diffuse pollutant loads from MAL watershed, through flow monitoring and 
Table 5 Correlation analysis of EMCs with rainfall characteristics

\begin{tabular}{lrrrrr}
\hline $\begin{array}{l}\text { Water quality } \\
\text { parameters }\end{array}$ & $\begin{array}{l}\text { Rainfall } \\
(\mathrm{mm})\end{array}$ & $\begin{array}{l}\text { Time } \\
(\mathrm{h})\end{array}$ & $\begin{array}{l}\text { Rainfall } \\
\text { intensity }(\mathrm{mm} / \mathrm{h})\end{array}$ & $\begin{array}{l}\text { Total } \\
\text { runoff }\left(\mathrm{m}^{3}\right)\end{array}$ & $\begin{array}{c}\text { Rainfall } \\
\text { runoff }\left(\mathrm{m}^{3} / \mathrm{s}\right)\end{array}$ \\
\hline BOD $(\mathrm{mg} / \mathrm{L})$ & -0.10 & -0.04 & 0.02 & 0.04 & 0.07 \\
COD $(\mathrm{mg} / \mathrm{L})$ & $-\mathbf{0 . 6 8}$ & -0.09 & -0.50 & $-\mathbf{0 . 3 3}$ & $\mathbf{- 0 . 2 9}$ \\
Ammonia $(\mu \mathrm{g} / \mathrm{L})$ & 0.33 & -0.16 & 0.41 & 0.43 & $\mathbf{0 . 4 4}$ \\
Nitrate $(\mu \mathrm{g} / \mathrm{L})$ & 0.15 & -0.09 & 0.08 & 0.19 & 0.19 \\
TKN $(\mu \mathrm{g} / \mathrm{L})$ & 0.05 & 0.37 & -0.09 & -0.21 & $\mathbf{- 0 . 2 4}$ \\
Hardness $(\mathrm{mg} / \mathrm{L})$ & $\mathbf{0 . 3 3}$ & 0.50 & -0.43 & -0.22 & $\mathbf{- 0 . 2 3}$ \\
TDS $(\mathrm{mg} / \mathrm{L})$ & 0.42 & 0.10 & 0.32 & 0.21 & 0.19 \\
TSS $(\mathrm{mg} / \mathrm{L})$ & $\mathbf{0 . 9 4}$ & -0.14 & $\mathbf{0 . 9 1}$ & $\mathbf{0 . 9 9}$ & $\mathbf{0 . 9 8}$ \\
Chlorides $(\mathrm{mg} / \mathrm{L})$ & 0.14 & 0.47 & 0.06 & 0.09 & 0.07 \\
Sulfates $(\mathrm{mg} / \mathrm{L})$ & $\mathbf{0 . 6 2}$ & -0.05 & 0.58 & 0.57 & $\mathbf{0 . 5 6}$ \\
Phosphate $(\mathrm{mg} / \mathrm{L})$ & 0.29 & 0.44 & 0.19 & 0.23 & 0.20 \\
Fluorides $(\mathrm{mg} / \mathrm{L})$ & -0.18 & 0.11 & -0.26 & -0.16 & -0.15 \\
TC $(\mathrm{MPN} / 100 \mathrm{~mL})$ & $\mathbf{0 . 7 0}$ & -0.43 & 0.83 & $\mathbf{0 . 6 8}$ & $\mathbf{0 . 7 0}$ \\
\hline
\end{tabular}

grab sampling of water from rainfall-runoff event were studied. The EMCs of diverse forms of organics, suspended solids, and nutrients were estimated. Field monitoring was conducted over ten storm events from 2006 to 2007 using manual sampling methods. EMC of individual runoff event was estimated for each water quality constituent based on the flow rate and concentration data of runoff discharge. The average EMCs of BOD, COD, ammonia, TKN, nitrate, hardness, TDS, TSS, chlorides, sulfates, phosphate, fluorides and TC of the MAL were $21.82 \mathrm{mg} / \mathrm{L}, 73.48 \mathrm{mg} / \mathrm{L}$, $72.68 \mu \mathrm{g} / \mathrm{L}, 229.87 \mu \mathrm{g} / \mathrm{L}, 15.32 \mu \mathrm{g} / \mathrm{L}, 11.36 \mathrm{mg} / \mathrm{L}, 117.44$ $\mathrm{mg} / \mathrm{L}, 108.64 \mathrm{mg} / \mathrm{L}, 117.64 \mathrm{mg} / \mathrm{L}, 135.82 \mathrm{mg} / \mathrm{L}, 0.08 \mathrm{mg} /$ $\mathrm{L}, 0.85 \mathrm{mg} / \mathrm{L}$ and $2,827 \mathrm{MPN} / 100 \mathrm{~mL}$, respectively. The results showed a strong correlation of pollutant characteristics with rainfall intensity and total runoff flows. The results provide principal information for the management of NPS pollutants entering the river basin and would be helpful to perform diffuse pollution modeling studies to evaluate the pollutant loading to the river system.

Acknowledgments The authors are indebted to the laboratories facility provided by TERI and TERI University to conduct the experiments.

Open Access This article is distributed under the terms of the Creative Commons Attribution License which permits any use, distribution and reproduction in any medium, provided the original author(s) and source are credited.

\section{References}

(1998) Standard methods for the examination of water and wastewater, 20th edn. American Public Health Association/American Water Works Association/Water Environment Federation, Washington, DC

Ackerman D, Schiff K (2003) Modeling storm water mass emissions to the Southern California Bight. J Environ Eng ASCE 129(4):308-317
Bhargava DS (1983) Most rapid BOD assimilation in Ganga and Yamuna rivers. J Environ Eng ASCE 109(1):174-188

Bhargava DS (1986) DO Sag model for extremely fast river purification. J Environ Eng 112(3):572-585

Candela A, Freni G, Mannina G, Viviani G (2009) Quantification of diffuse and concentrated pollutant loads at the watershedscale: an Italian case study. Water Sci Technol 59(11): $2125-2135$

Chui TW, Mar BW, Hornet RR (1982) A pollutant loading model for highway runoff. J Environ Eng ASCE 108(6):11931210

Cox BA (2003) A review of dissolved oxygen modelling techniques for lowland rivers. Sci Total Environ 314-316:303-334

CPCB (2000) Water quality status of Yamuna River, assessment and development study of river basin series (ADSORBS), ADSORBS/32. Central Pollution Control Board, Delhi

CPCB (2007) Water quality status of River Yamuna (1999-2005), assessment and development study of river basin series (ADSORBS), ADSORBS/41. Central Pollution Control Board, Delhi

Crabtree B, Moy F, Whitehead M, Roe A (2006) Monitoring pollutants in highway runoff. Water Environ J 20:287-294

Delhi Master Plan 2021, N.A. The perspective of year 2021 Delhi-a vibrant economy. http://delhi-masterplan.com. Accessed 3 Feb 2011

Freni G, Mannina G, Viviani G (2010) Emission standards versus immission standards for assessing the impact of urban drainage on ephemeral receiving water bodies. Water Sci Technol 61(6):617-629

Graves GA, Wan YS, Fike DL (2004) Water quality characteristics of storm water from major land-uses in South Florida. J Am Water Resour Assoc 40(6): 1405-1419

Indiastat.Com Revealing India Statistically. http://www.indiastat. com/demographics. Accessed 2 Feb 2011

International Joint Commission (1974) Management programs, effects of research, and present land use activities on water quality of the Great Lakes (2 vols.). Pollution from Land Use Activities Reference Group (PLUARG). International Joint Commission, Windsor

Jain P (2009) Sick Yamuna, sick Delhi-searching a correlation. A report by PEACE Institute Charitable Trust, Delhi

Jamwal P, Mittal AK, Mouchel JM (2008) Effects of urbanisation on the quality of the urban runoff for Delhi watershed. Urban Water J 5(3):247-257 
Kannel PR, Kanel SR, Lee S, Lee YS, Gan TY (2011) A review of public domain water quality models for simulating dissolved oxygen in rivers and streams. Environ Model Assess 16(2):183-204

Kazmi AA, Hansen IS (1997) Numerical models in water quality management: a case study for the Yamuna river (India). Water Sci Technol 36(5):193-200

Kazmi AA, Agrawal L (2005) Strategies for water quality management of Yamuna river, India. In: Proceedings of third international symposium on South East Asian water environment, Bangkok, pp 70-80

Kim LH, Kayhanian M, Zoh KD, Stenstrom MK (2005) Modeling of highway stormwater runoff. Sci Total Environ 348(1-3):1-18

Kim G, Chung S, Lee C (2007a) Water quality of runoff from agricultural-forestry watersheds in the Geum River Basin, Korea. Environ Monit Assess 134(1-3):41-52

Kim LH, Ko SO, Jeong S, Yoon J (2007b) Characteristics of washedoff pollutants and dynamic EMCs in parking lots and bridges during a storm. Sci Total Environ 376(1-3):178-184

Lee JH, Bang KW, Ketchum LH, Choe JS, Yu MJ (2002) First flush analysis of urban storm runoff. Sci Total Environ 293(1-3):63-75

Mallin MA, Williams KE, Esham EC, Lowe RP (2000) Effect of human development on bacteriological water quality in coastal watersheds. Ecol Appl 10:1047-1056

McLeod SM, Kells JA, Putz GJ (2006) Urban runoff quality characterization and load estimation in Saskatoon, Canada. J Environ Eng ASCE 132(11):1470-1481

Misra AK (2011) Impact of urbanization on the hydrology of Ganga basin (India). Water Resour Manag 25(2):705-719. doi:10.1007/ s11269-010-9722-9

National Capital Region Planning Board Report, n.a. http://ncrpb.nic.in/ pdf_files/13dmodified_ch09irrigation.pdf. Accessed on 14 Nov 2011

National River Conservation Directorate, River Action Plan, Ministry of Environment and Forests, India. http://envfor.nic.in/nrcd/ NRCD/YAP.htm. Accessed 4 Feb 2011

Neitsch SL, Arnold JG, Kiniry JR, Williams JR (2005) Soil and water assessment tool theoretical documentation and user's manual. Version 2005, GSWR. Agricultural Research Service \& Texas Agricultural Experiment Station, Temple Texas

Paliwal R, Sharma P, Kansal A (2007) Water quality modelling of the river Yamuna (India) using QUAL2E-UNCAS. J Environ Manag 83(2):131-144

Parmar DL, Keshari AK (2011) Sensitivity analysis of water quality for Delhi stretch of the River Yamuna, India. Environ Monit Assess. doi:10.1007/s10661-011-2055-1
Planning Commission Report, n.a., Memorandum of understanding between Uttar Pradesh, Haryana, Rajasthan, Himachal Pradesh and National Capital Territory of Delhi regarding allocation of surface flow of Yamuna. http://planningcommission.nic.in/ reports/sereport/ser/wjc/wjc_ch1.pdf. Accessed on 14 Nov 2011

Sharma D, Singh RK (2009) DO-BOD modeling of River Yamuna for national capital territory, India using STREAM II, a 2D water quality model. Environ Monit Assess 159(1-4):231-240

Soil Conservation Service (1964) National engineering handbook, Section 4, Hydrology. Department of Agriculture, Washington, p 450

Soni V, Gosain AK, Datta PS, Singh D (2009) A new scheme for large-scale natural water storage in the floodplains: the Delhi Yamuna floodplains as a case study. Curr Sci 96(10):1338-1342

SRTM 90m Digital Elevation Data. The CGIAR Consortium for Spatial Development (CGIAR-CSI) Applying GeoSpatial Science for a sustainable future. http://srtm.csi.cgiar.org/. Last Updated: August 19, 2008. Accessed 9 May 2006

Terzakis S, Fountoulakis MS, Georgaki I, Albantakis D, Sabathianakis I, Karathanasis AD, Kalogerakis N, Manios T (2008) Constructed wetlands treating highway runoff in the central Mediterranean region. Chemosphere 72:141-149

Tong STY, Chen W (2002) Modeling the relationship between land use and surface water quality. J Environ Manag 66(4):377393

Tsihrintzis VA, Hamid R (1997) Modeling and management of urban runoff quality: a review. Water Resour Manag 11(2):137-164

Ukabiala CO, Nwinyi OC, Abayomi A, Alo BI (2010) Assessment of heavy metals in urban highway runoff from Ikorodu expressway Lagos, Nigeria. J Environ Chem Ecotoxicol 2:34-37

Van der Velde G, Leuven AMJ, Ragas AMJ, Smits AJM (2006) Living rivers: trends and challenges in science and management. Hydrobiologia 565:359-367

Vaze JS, Chiew FWS (2004) Nutrient loads associated with different sediment sizes in urban stormwater and surface pollutants. J Environ Eng 130:391-396

Yusop Z, Tan LW, Ujang Z, Mohamed M, Nasir KA (2005) Runoff quality and pollution loadings from a tropical urban catchment. Water Sci Technol 52(9):125-132

Zhao JW, Shan BQ, Yin CQ (2007) Pollutant loads of surface runoff in Wuhan City Zoo, an urban tourist area. J Environ Sci China 19(4):464-468

Zoppou C (2001) Review of urban storm water models. Environ Model Softw 16(3):195-231 